NBER WORKING PAPER SERIES

\title{
WORKLIFE DETERMINANTS OF RETIREMENT INCOME DIFFERENTIALS BETWEEN MEN AND WOMEN
}

\author{
Phillip B. Levine \\ Olivia S. Mitchell \\ John W. Phillips \\ Working Paper 7243 \\ http://www.nber.org/papers/w7243
}

\author{
NATIONAL BUREAU OF ECONOMIC RESEARCH \\ 1050 Massachusetts Avenue \\ Cambridge, MA 02138 \\ July 1999
}

We acknowledge research support from the AARP and the Pension Research Council at the University of Pennsylvania, and computer support from Penn's Population Aging Research Center. The views expressed in this paper are those of the authors and not those of the National Bureau of Economic Research.

(C) 1999 by Phillip B. Levine, Olivia S. Mitchell, and John W. Phillips. All rights reserved. Short sections of 
text, not to exceed two paragraphs, may be quoted without explicit permission provided that full credit, including (C) notice, is given to the source.

Worklife Determinants of Retirement Income

Differentials Between Men and Women

Phillip B. Levine, Olivia S. Mitchell, and John W. Phillips

NBER Working Paper No. 7243

July 1999

JEL No. J26, J16

\begin{abstract}
Women enter retirement having spent fewer years in market work, earned less over their lifetimes, and worked in different jobs than men of the same age. This study examines whether these differences in work-life experiences help explain why many women end up withlower levels of retirement income in old age. We use the Healthand Retirement Study (HRS), which provides information on labor market histories along with the ability to predict retirement income from employer pensions, social security benefits, and investment returns. We document differences in anticipated retirement income by sex that exist largely between nonmarried men and women. Multivariate models show that 85 percent of this retirement income gap can be attributed to differences in lifetime labor market earnings, years worked, and occupational segregation by sex. Our results suggest that as women's work-life experiences become more congruent with men's over time, the gap in retirement income between men and women may shrink.
\end{abstract}

Phillip B. Levine

Department of Economics

Wellesley College

Wellesley, MA 02181

and NBER

plevine@wellesley.edu

John W. Phillips

Population Studies Center

University of Pennsylvania

Philadelphia, PA 19104-6218

jwp@pop.upenn.edu
Olivia S. Mitchell

Wharton School

3641 Locust Walk, 304 CPC

University of Pennsylvania

Philadelphia, PA 19104-6218

and NBER

mtichelo@wharton.upenn.edu 
Persons age 65 and over were once among the poorest members of the U.S. population, but today the rate of poverty for the elderly is at least as low as that of younger people. Nevertheless there remain pockets of elderly poverty. Specifically, women over the age of 65 are about twice as likely to live in poverty in the U.S. as are similarly-aged men. ${ }^{1}$

Previous research has emphasized widowhood as an important determinant of this differential (Weir and Willis, forthcoming; Burkhauser et al., 1991; Boskin and Shoven, 1988), but another factor that may contribute to women's disadvantage in old age is their different labor market experiences during their prime working years. Women's lower wages, fewer years of work, and concentration in female-dominated jobs may reduce retirement income through lower pension and Social Security retirement benefits and lower levels of savings. Both forms of retirement benefits would tend to favor men since they typically reward those with higher-paying jobs and more years of paid work. Similarly, their lower level of lifetime earnings may lead women to save less. Occupational segregation by sex may contribute to the differential as well because female-dominated jobs tend to pay less and may offer fewer benefits.

In this paper we use the Health and Retirement Study (HRS) to evaluate the role that differences in labor market experiences play in explaining why older women face relatively poor retirement income prospects. We begin by presenting a series of descriptive analyses regarding the levels of retirement income by sex, race, marital status, and source of income. We find that the median wealth of a married couple on the verge of retirement today exceeds half a million dollars, with substantial accumulations in Social Security, pensions, housing and other holdings. By contrast, 
nonmarried people approaching retirement have considerably less wealth. More than half of the nonmarried population has less than $\$ 200,000$, counting all forms of retirement wealth. Few can look forward to future pension benefits, and even Social Security wealth is not large. Within the nonmarried group, women are particularly disadvantaged, having a level of wealth about one-quarter lower than that of nonmarried men. This difference is concentrated among the White population, since Blacks and Hispanics have very low and relatively similar levels of retirement wealth.

Then we present a statistical analysis of the determinants of these differences in anticipated retirement income, which confirms that differences in lifetime labor market experiences lower women's retirement income relative to men. Lower lifetime average earnings, fewer years in the paid labor market, and occupational segregation by sex all contribute to this gap. Estimates indicate that $85 \%$ of this retirement income gap between nonmarried men and women can be attributed to differences in these factors. Our results suggest that as women's work-life experiences become more congruent with men's over time, the gap in retirement income between men and women may shrink.

\section{Prior Studies}

Research examining differences in labor market rewards by gender have generally focused on the wages of currently employed workers. Two distinct research strands may be discerned in this literature. One approach considers whether observed wage gaps can be "explained" or accounted for in a statistical sense, by differences in characteristics likely to be related to worker productivity, such as age, education, and labor market experience. To the extent that a wage differential exists after

\footnotetext{
${ }^{1}$ For an extensive list of references see Levine, Mitchell, and Moore (forthcoming).
} 
controlling for these factors, it is typically attributed to labor market discrimination. This strand of the literature consistently finds evidence of discrimination by this definition. ${ }^{2}$

A second approach used in explaining sources of the male/female wage gap evaluates occupational segregation and its impact on wage differentials. Studies have shown that more than half of all women would have had to move from female-dominated to male-dominated jobs in 1990 if the occupational distribution of men and women were to be equalized. ${ }^{3}$ This estimate is lower than the 70\% figure that applied in 1970. Although jobs dominated by women tend to pay less than jobs dominated by men, determining whether this gap is due to discrimination also requires other job attributes and productivity-related differences among the holders of those jobs to be held constant. ${ }^{4}$ Therefore, the statistical methodology typically employed in this literature includes a control for the percentage of women in a worker's occupation in a wage regression that also controls for these other factors. Results from studies that employ this methodology tend to find that, ceteris paribus, people employed in an occupation dominated by women earn somewhat lower wages. ${ }^{5}$

While the literature on younger workers is lengthy, few researchers have followed workers into retirement to determine whether labor market differences continue to have an impact at older ages. Levine, Mitchell, and Moore (forthcoming) is an exception to this generalization; that study sought to determine whether differences in lifetime labor market attachment accounted for differences by sex in projected retirement income. Results from that work indicated that previous employment played a large

\footnotetext{
${ }^{2}$ See Blau and Kahn (1997); Gunderson (1989); and Blau and Ferber (1987).

${ }^{3}$ See Blau, Ferber, and Winkler (1998) and Blau, Simpson, and Anderson (1998).

${ }^{4}$ See Macpherson and Hirsh (1995).

${ }^{5}$ For evidence on this point see Sorenson (1989 and 1990); Killingsworth (1990); Filer (1989) and Johnson and Solon (1986).
} 
role, but that health and family responsibilities had only tiny measured impacts on projected retirement incomes. One drawback of that study was that only self-reported labor market data could be used, rather than more precise data taken from administrative records on labor market experience. In addition, that analysis focused on total retirement income and did not consider its components separately. The present study uses better quality data than heretofore available on pension and Social Security wealth, and explores how labor market and other factors influence anticipated retirement income overall, and by its source.

\section{Description of the Data}

This analysis is undertaken using the Health and Retirement Study (HRS), which is a nationally representative sample of U.S. households drawn from a cohort on the verge of retirement (age 51-61 in 1992). ${ }^{6}$ The HRS provides extensive and very detailed demographic, health, wealth, income, and family structure data for respondents and their spouses. We also utilize information from two additional files containing invaluable information on respondents' pension and Social Security benefits. One file, known as the Earnings and Benefits File (EBF), provides measures of expected retirement income derived from Social Security benefits as well as labor market history data. A second file, the Pension Provider File (PPF), contains estimates of anticipated pension benefits. These merged files have been obtained for a majority of HRS respondents who gave permission to link their survey data with administrative records supplied by the Social Security Administration, and also with pension plan descriptions provided by respondents' employers. ${ }^{7}$ Together, the HRS, EBF, and PPF data represent

${ }^{6}$ For more detail on the HRS dataset see www.umich.edu/ hrswww; the Data Appendix describes variable creation for the present study.

${ }^{7}$ Because of the confidential nature of these data, researchers may access them only under restricted conditions; see www.umich.edu/ hrswww for details. 
one of the richest data resources available to analyze retirement. There is no other current data source with equivalently detailed linked administrative records for this cohort. ${ }^{8}$

Using these three files, we compute anticipated retirement wealth for each household. ${ }^{9}$ This wealth value is allocated or spread over the household's retirement period using conventional annuity factors. ${ }^{10}$ In other words, we take each household's assets and divide them up to reflect the annual payments that a given level of wealth would yield if it were drawn down to zero over the household's remaining life expectancy. The annuity factors used to convert wealth to annual income flows reflect the different life expectancies of men and women at different ages. Thus annuity factors for older respondents and men are smaller than those for younger respondents and women, since older respondents and men have shorter life expectancies than younger respondents and women. Turning a

\footnotetext{
${ }^{8}$ The availability of the Social Security and pension match data makes the HRS uniquely valuable among all datasets covering retiring Americans. Though Social Security benefits were calculated for most of the age-eligible HRS respondents in the sample, in a few cases this information could not be computed and the respondent had to be omitted from the sample analyzed in this paper (more detail on sample sizes is given below). One reason for missing Social Security benefits was that respondents gave permission for the University of Michigan to request their Social Security records, but no match was obtained because their records did not match SSA identification information. Another reason is that the Social Security Administration excluded from the match file any respondents receiving Social Security Disability Insurance benefits. Also some age-eligible respondents declined to sign the release form permitting their Social Security data to be matched with the HRS. In this study we rely on Social Security wealth estimates as well as earnings histories provided in the EBF, so respondents lacking these data are excluded from our analysis. This selection might bias results if those with an EBF file differ from those without a match; we have no evidence that results are biased and indeed respondents lacking consents for a Social Security match are quite diverse. Thus some of the very wealthy (having high levels of financial assets) did not sign the special release, while some Blacks and Hispanics also did not provide consent. Inasmuch as missing EBF matched records applies to people at both ends of the wealth distribution, we believe the direction of potential bias is ambiguous. More formally, an econometric solution to this sample issue would require finding an instrumental variable correlated with the probability of having an EBF match but uncorrelated with Social Security wealth. Such a variable does not exist in our sample.

${ }^{9}$ Dollar figures throughout this paper are in constant 1992 dollars.

${ }^{10}$ Levine, Mitchell, and Moore (forthcoming) discuss several ways to model well being; here we simply focus on levels of retirement income, since these are more readily understood. Burkhauser et al. (1985), Moon (1977), and Hurd (1989) employ similar measures.
} 
stock of wealth into an annual income flow makes it easier to interpret and understand exactly what older Americans command by way of retirement resources.

In order to evaluate HRS respondents' access to anticipated retirement income, we must distinguish between an individual's own resources and those available to his or her household. ${ }^{11}$ For the present analysis, we assess projected retiree wealth available within a household without seeking to divide assets across individual members of a married couple. In other words, the model assumes that retirement income generated by different assets is equally available to a husband and a wife in a married couple. In this way, we presume that household resources are consumed jointly as long as both spouses are living. ${ }^{12}$ As a result, sex differences in retirement well being will result only from measured differences in the well being of nonmarried men and women. ${ }^{13}$

We develop and use two indicators to capture patterns in respondent employment and earnings over their working lives. One is average annual earnings between the respondent's $20^{\text {th }}$ and $50^{\text {th }}$ birthday using data on annual pay up to the Social Security earnings ceiling. ${ }^{14}$ We call this measure "prime-age" earnings since it covers the period beginning with age 20, when most of the respondents

\footnotetext{
${ }^{11}$ All values are computed assuming retirement will occur at age 62. See the Data Appendix for more discussion of this point.

12 After one party dies, the surviving spouse is assumed to keep half the pension in a joint-and-survivor arrangement, and Social Security benefits continue for eligible widow(ers). Housing and other wealth is bequeathable to the surviving spouse in its entirety. While the HRS dataset does not report ownership of assets within couples, other research has acknowledged the potential for intrahousehold bargaining between married couples (McElroy, 1990). Incorporating the possibility of spousal behavior of this sort may be feasible with other data sources.

${ }^{13}$ Nonmarried persons in the HRS are those who are not currently married; this population includes the never married, the divorced, and the widowed, based on self-reported marital status. Married persons are likewise self reported. Practically speaking, there are slight differences in married men's and women's measured resources in the HRS because the age-eligible women in HRS couples have husbands that are slightly older than women in couples with HRS age-eligible men.
} 
would have completed their schooling, and it ends at age 50, after which labor market activity could be influenced by early retirement preparations. In general, we anticipate that people with higher prime-age earnings will anticipate higher retirement wealth and hence more annual income in retirement. This is a reflection of the way pension formulas work, and also the way earnings are translated into Social Security benefits. Empirically, of course, it is of interest to estimate the specific way in which higher earnings result in higher retirement income. The second indicator of labor market attachment used here is a count of the number of years of Social Security covered employment up to the respondent's $50^{\text {th }}$ birthday. ${ }^{15}$ This factor is invaluable in assessing how another year of work is converted into additional retirement income, via pension, Social Security, and saving mechanisms.

To examine the impact of occupational segregation, we determined each worker's longest job along with a summary measure indicating the occupation of that job. ${ }^{16}$ Following the literature cited above, we sought to determine whether having a higher concentration of women in a given occupation also has long-term negative consequences for retirement income of people in that occupation. This is tested in our multivariate model by assessing whether a higher proportion of women in the worker's occupation on her/his longest job is associated with lower retirement income.

The remaining information on respondent characteristics is available directly from the HRS. Thus, for instance, survey respondents supplied extensive information on the economic, social,

14 The derivation of the prime-age earnings measure is described in Mitchell, Olson, and Steinmeier (forthcoming).

${ }^{15}$ Variable creation is described in Mitchell, Olson, and Steinmeier (forthcoming).

16 The Data Appendix describes creation of this occupation variable. One limitation of the HRS data used here is that we can only identify each worker's occupation at the 2-digit level; this restriction was required in order to obtain the earnings and Social Security benefits data key for retirement well being computations. We are able, therefore, to identify professional and technical occupations separately from 
demographic, and other attributes of household members. The survey delved into household members' incomes, assets, debt, and health for respondents, age 51-61 in 1992, and their spouses of any age.

Two main criteria were used to generate the sample for empirical analysis. We restricted the respondent sample to include only those who were "age-eligible", namely the 9,714 respondents who were age 51-61 in 1992. It should be noted that people in this age bracket were interviewed as well as their spouses (irrespective of the spouse's age). ${ }^{17}$ In addition, the sample included only those respondents and spouses who furnished a consent form, for whom the Social Security Administration could locate a matched file, and who were not receiving disability benefits at the time of the 1992 interview. These restrictions were required in order to obtain anticipated Social Security benefits. The analysis sample consists of 5,684 individuals. ${ }^{18}$

\section{Methodological Approach}

The analysis that follows first describes HRS respondents' wealth levels along with the anticipated annual income flows they represent. Next, we estimate multivariate models of annual retirement income for men and women. Our methodological approach is informed by the approaches followed in prior studies that have sought to explain differences in pay for active workers. In this analysis, though, we focus on the influence of labor market history on retirement income differences by sex. Along with measures of years in the labor market, average prime-age pay, and a measure of how sex-segregated the respondent's longest job was, we also include socioeconomic factors (e.g.

craft occupations but cannot distinguish further within these categories. Future researchers with access to narrower occupational definitions might assess the impact of such occupational aggregation.

${ }^{17}$ In any event, spouses' wealth is included in the analysis irrespective of the spouse's age.

${ }^{18}$ To arrive at the final sample, two minor sample restrictions were made as well. Some households were dropped because they lacked a "financial respondent" responsible for providing financial data to the interviewers. We also omit respondents whose race/ethnic status was not White, Black, or Hispanic. 
education, marital history, and number of children) and race/ethnic indicators. In the case of married respondents, we also include the same measures for the respondent's spouse, since his/her characteristics may also contribute to differences in family resources available in retirement. These regression models are estimated separately by sex and marital status so that results can be compared across groups. Identical model specifications are estimated for the three dependent variables of key interest, namely income flows from Social Security, pensions, and financial wealth including housing.

More formally, the multivariate model estimated uses the natural $\log$ of retirement income $R Y_{i g}$ where $i$ refers to the individual; $g$ refers to the respondent's sex (f for female, $\mathrm{m}$ for male); WH is lifetime pay and work experience ("work history"); \%FEM is the fraction of women in the respondent's longest occupation; $X$ is a vector of age, ethnicity, previous marital status, number of children, and education; and $u$ refers to a disturbance term that captures otherwise unmeasured characteristics:

$$
\ln (R Y)_{i g}=\left(W H_{i g}\right) b_{1 g}+(\% F E M)_{i g} b_{2 g}+X_{i g} b_{3 g}+u_{i g}
$$

For married respondents, analogous variables are included for spouse's characteristics. Levine, Mitchell and Moore (forthcoming) and Blau and Graham (1990) estimate similar specifications.

One potential shortcoming of this analysis is that there may be dual causality in the regression models between retirement income, on the one hand, and earnings as well as work years, on the other. That is, more work at higher pay would be anticipated to raise retirement income, but conversely, having higher retirement assets might discourage people from working more years or seeking out higher pay. In order to reduce the possibility of endogeneity of these variables, the labor market variables we adopt are strictly retrospective measures. That is, a worker's years of labor market experience are measured up to age 50 but not thereafter. Average pay is likewise computed based on the worker's 
Social Security earnings reported between age 20 and 50; and the occupation for which the fraction female refers to is the respondent's longest job. ${ }^{19}$ Nevertheless, the possibility remains that retirement wealth considerations may have affected the labor market behavior of individuals before age 50 .

Having in hand estimates of the effects of each factor on projected retirement income, we then evaluate how much of anticipated retirement income differences by sex could be attributed to differences in the workers' characteristics. ${ }^{20}$ With regard to differences in labor market characteristics, we ask the hypothetical question: how much would the gap in projected retirement income decrease if

${ }^{19}$ Similar issues of endogeneity may be present regarding decisions made over the lifecourse, including educational attainment, marital history, and childbearing. To assess the influence of this potential problem, we have also estimated reduced form models that include only the labor market history measures with no other covariates and obtained qualitatively similar results to those reported below.

${ }^{20}$ Oaxaca (1973) devised the statistical technique used here to show how differences in outcomes might be allocated to different sources. In the present context, we have adapted this approach to decompose the difference in projected log annual retirement income between older women and men into two parts: the portion due to differences in characteristics that differ by sex, and the portion due to differences in returns to those characteristics between the sexes. These analyses are conducted separately by marital status groups. We use women's returns to characteristics to determine how much of the gap in log retirement income would be closed if women's characteristics became like those of men. Specifically, we compute:

$$
\bar{R} \bar{Y}^{m}-\bar{R} \bar{Y}^{f}=\sum_{i=1}^{k} \beta_{i}^{f} \cdot\left(\bar{X}_{i}^{m}-\bar{X}_{i}^{f}\right)+\sum_{i=1}^{k} \bar{X}_{i}^{m} \cdot\left(\beta_{i}^{m}-\beta_{i}^{f}\right),
$$

where $R Y$ represents a particular measure of economic well-being; $b$ represents the vector of regression coefficients estimated using the multivariate model described above; the $X$ values represent a vector of mean characteristics, $f$ and $m$ represent women and men, respectively; and $k$ indexes characteristics. The first expression on the right hand side of this equation is said to represent the "explained" part of the differential in retirement income because it is attributed to the different characteristics of men and women. The second expression is said to represent the "unexplained" part of the differential because it would result in differences in income even if men and women had the same characteristics. Our simulation computes the percentage reduction in the retirement income gap between men and women that would occur if both had identical characteristics. Formally, this involves estimating:

$$
\% \text { Gap }=\frac{\sum_{i}^{k} \beta_{i}^{f} \cdot\left(\bar{X}_{i}^{m}-\bar{X}_{i}^{f}\right)}{\bar{R} \bar{Y}^{m}-\bar{R} \bar{Y}^{f}} \cdot 100
$$

This expression represents the gap in log retirement income that can be "explained" by differences in characteristics as a percentage of the size of the gap. Below we also compute the dollar contribution to the gap in retirement income by applying the percentages to the dollar gap in projected annual retirement income. 
lifetime labor market characteristics of men and women were identical? In other words, based on estimated returns to these characteristics, we predict what women's retirement income would be if they had characteristics that were equal in value to those of men, on average. Since men tend to have had stronger labor force attachment during their working years, one would expect the gap between men and women's projected retirement income to be smaller, or potentially even zero, when it is based upon this prediction. Finally, we estimate and report the dollar reduction in the gender gap in projected retirement income between the predicted and observed level.

We conduct this decomposition for nonmarried men and women exclusively. As indicated previously, we assign household resources equally to husbands and wives, so that married men and women are defined to have equal retirement wealth. Using the HRS, we can identify differences in retirement wealth among married men and women because both members of the couple need not be age-eligible, which is a requirement for inclusion in our sample, and the characteristics of the ageineligible men and women may differ. Without such cases, retirement wealth would be identical and there would be no gender gap to explain. Therefore, we restrict this part of the analysis to nonmarried men and women only. 


\section{Empirical Findings}

\section{$\underline{\text { Descriptive Statistics }}$}

Median retirement wealth for HRS respondents appears in Table 1 by sex, marital status, and race/ethnic group. ${ }^{21}$ Retirement wealth levels are quite substantial for married couples, exceeding half a million dollars when pensions, Social Security, and other financial assets are counted. (Married men and women have similar levels of retirement wealth because retirement wealth is pooled at the household level.) By contrast, projected retirement wealth for nonmarried people appears much lower, totaling only about one-third as much as for married couples (between $\$ 157,000$ and \$192,000). ${ }^{22}$ There are also striking sex differences disfavoring women; that is, nonmarried men have almost 20 percent more retirement wealth than nonmarried women.

These overall differences become even sharper when we examine the subcomponents of wealth. For example, married couples' Social Security wealth totals about $\$ 180,000$, a figure not too different from their \$160,000 in housing and net financial assets. Their pension wealth amounts to approximately $\$ 98,000-\$ 121,000$. By contrast, Social Security wealth represents a dominant portion of total wealth for nonmarrieds, housing is less important, and - particularly striking - pension wealth is very tiny indeed. The median nonmarried woman, for instance, has no pension wealth at all, compared to her nonmarried male counterpart who has $\$ 26,000$, and her married female counterpart with close to $\$ 100,000$ in household pension assets.

\footnotetext{
${ }^{21}$ We focus on medians since differences in averages may be driven by a relatively small number of individuals with very large levels of wealth. Mean levels used in the decomposition analysis are reported in Appendix Table 1.

${ }^{22}$ All dollar figures in this paper are in $\$ 1992$. The difference in wealth levels by marital status goes well beyond differences in household size since a simple division by two of a married household's wealth still
} 
Patterns of retirement wealth by race/ethnic status in Table 1 indicate that the relative disadvantage faced by nonmarried women versus men is most concentrated among the White population. This is because the wealth gap for Black and Hispanic nonmarried men versus women is very small or even nonexistent. Thus nonmarried Black women actually have higher levels of total wealth $(\$ 106,000)$ than their nonmarried Black male counterparts $(\$ 75,000)$; for Hispanics total wealth is $\$ 91,000$ for nonmarried men and $\$ 72,000$ for nonmarried women. Pension wealth is effectively nil for Black and Hispanic nonmarried people, and other wealth is similarly miniscule. In sum, differences in retirement wealth between Whites and minorities are considerably larger than those between men and women.

How these wealth figures translate into annual retirement income flows by sex, marital status, and race/ethnicity is evident from Table 2 . The retirement assets shown previously will produce annual income equivalents for married men and women that are similar to each other, on the order of about $\$ 28,000-29,000$ per year. Over one-third of the anticipated retirement income is attributable to Social Security benefits totaling about $\$ 10,000$ per year for the median married household, exceeding the annuitized value of housing and financial wealth that totals about \$8,000-9,000 annually. Median pension income for married couples is somewhat lower, at about $\$ 5,000-6,000$ per year. ${ }^{23}$

surpasses that of nonmarried individuals. Moreover, equivalence scales typically assign a value of less than two to adequately correct for differences in household size (c.f. Ruggles, 1990; Nelson, 1993).

23 Tables 1 and 2 include respondents with zero values for all these wealth sources, but in the multivariate analysis we exclude those with zero, or negative, wealth values. While some may anticipate retirement income from other sources, we expect this to be true for a very small number of respondents. For example, only 16 individuals out of over 9,000 in the HRS report receiving annual income transfers from their parents. 
Projected annual retirement income for nonmarried people is expected to be only about onehalf to one-third the size of married couples' income, at $\$ 13,000$ for nonmarried men and $\$ 9,000$ for nonmarried women. The relative disadvantage of nonmarried women stems partly from the fact that they are anticipated to live longer than men on average, which makes the gap in annual retirement income flows larger than the wealth gap. Furthermore, nonmarried people probably require more than half a married couple's income to maintain a comparable living standard. Hence the finding that nonmarried respondents expect so much less income in retirement than do married couples does not bode well for their prospective retirement well being.

Looking further at the components of retirement income flows, it appears that the redistributive nature of Social Security benefits somewhat narrows the retirement gap between nonmarried men and women. However, median expected annual benefit levels are low, on the order of $\$ 5,500$ for men and $\$ 3,600$ for women. A problem confronting the median nonmarried woman approaching retirement is that she has no pension wealth at all, whereas nonmarried men have small accumulations, and the median married couple can expect $\$ 5,000-6,000$ of pension income annually. Nonmarried men and women have similar levels of net financial and housing wealth, but it is worth pointing out that more nonmarried men have very high levels of other wealth, since the medians are similar but the means are higher for the men.

Finally, focusing on the differences in anticipated annual retirement income by race/ethnicity, we find that the median married Black couple would anticipate $\$ 19,000$ annually, and the married Hispanic couple $\$ 12,000-15,000$ annually. This compares to much lower levels expected by nonmarried persons, with Black and Hispanic women expecting \$4,000-6,000 per year in total income, and Black as well as Hispanic men anticipating income in the same range. Table 2 clearly shows minority groups' 
heavy reliance on Social Security since they can expect relatively little income from sources other than Social Security. These very low income levels do not differ much by sex for minorities.

\section{$\underline{\text { Regression Results }}$}

Moving beyond simple tabulations of the data, we next evaluate how changes in respondent characteristics might improve retirement well being. Specifically, we are interested in the "returns" that people anticipate receiving in the form of higher retirement income, for a given increase in earnings and work experience; we are also interested in the how the gender composition of jobs affects anticipated retirement well being. A full set of results from our multivariate statistical analysis controlling for these factors as well as other socioeconomic factors is reported in Appendix Table 2. To facilitate interpretation of these findings, however, we focus on the results reported in Table 3, which shows how a change in one of the labor market history variables of reasonable magnitude might be expected to influence the average person's annual retirement income. ${ }^{24}$

Simulations of this type are carried out for total retirement income and also for the three components of wealth. For example, the first panel of Table 3 shows how working an extra year between the ages of 20 and 50 influences overall retirement income as well as the three components of wealth. For nonmarried women, an additional year of work is found to have a very small positive effect (\$94) on total retirement income holding other things constant, but this estimate is not significantly different from zero. Although an extra year of work is estimated to actually reduce total retirement income for nonmarried men, that estimate also is not statistically significantly different from zero.

\footnotetext{
${ }^{24}$ Values are computed at the sample mean unless otherwise noted (reported in Appendix Table 1). We have also examined predicted changes in retirement income associated with changes in the labor market histories of spouses of married respondents; these prove to be similar to those for male and female married respondents themselves.
} 
By contrast, an additional year worked apparently reduces total retirement income for both married men and women, and now the estimates are statistically significant. This effect is the result of offsetting effects on the three main components of retirement income. That is, additional years of work translate into higher Social Security benefits for both groups (which was also true for nonmarried women). But an additional work year is associated with lower lifetime pension payments and with lower income from other assets. As discussed earlier, one explanation for this finding is potential endogeneity bias in which those with greater anticipated retirement income may work fewer years, even before the age of 50 .

Having higher lifetime earnings generally translates into higher anticipated retirement income levels for all groups, holding other factors constant. Thus an additional $\$ 1,000$ in average annual pay earned during the prime-age period (age 20-50) is associated with an additional $\$ 240-\$ 270$ per year in retirement income for women, and $\$ 360-\$ 570$ per year for men. This positive effect is robust across all retirement income components: that is, higher average prime-age earnings are consistently associated with higher Social Security income, pension income, and other income (although some of the estimated effects are not significantly different from zero).

It is also interesting that Social Security benefit formulas reward nonmarried persons more at the margin for higher earnings than they do married persons. This is because married couple benefits are heavily influenced by Social Security survivor payments that pay off in the event of the death of one spouse, and this valuable benefit stream is influenced only modestly by additional earnings during the prime-age period. By contrast, a nonmarried person's Social Security benefit is payable only as long as the retiree is alive; lacking the death benefit, retirement income streams become more closely earningslinked than is true for married persons. Also as a result, higher earnings translate directly into higher 
pension income, with somewhat higher effects for nonmarried men $(\$ 216)$ than for women $(\$ 130)$; this may be because men are covered by more generous pension benefit formulas than women. The fact that other income rises more for additional pay may suggest that personal saving is more feasible for those earning higher salaries.

Turning to the final labor market variable of interest, which is the proportion female in the respondent's "main" occupation, we find that this is associated with a statistically significant reduction in total retirement income for both married and nonmarried women, but not for either group of men. The effect is reasonably large for the nonmarried women, in particular; a 10-percentage point increase in the fraction of women in an occupation is associated with a decrease in nonmarried women's retirement benefits of $\$ 424$ per year. It is interesting that this negative effect is primarily effective through pension and other income, but not through Social Security. This may be because jobs dominated by women are less likely to provide generous pensions (and perhaps other benefits as well), so women's financial emergencies may result in lower eventual saving. ${ }^{25}$

\section{$\underline{\text { Decomposition Results }}$}

Having described how anticipated retirement income patterns vary across the population, we next decompose projected retirement income gaps into their component parts. This exercise asks the question: how would women fare in terms of retirement income if their labor market and other characteristics were to become equivalent to those of men? Specifically, we evaluate the difference in annual retirement income by sex that can be attributed to differences in labor market experience and

\footnotetext{
${ }^{25}$ For married respondents, increases in a spouse's years worked, level of earnings, and percentage of women in their occupation have similar effects to those found for the respondents themselves (not shown in Table 3).
} 
other factors. We conduct this exercise for nonmarried respondents only since we have assumed that resources are split evenly among married couples, eliminating the possibility of sex differentials in their retirement wealth.

The results of this analysis appear in Table 4, where we first note that nonmarried men anticipate receiving about $\$ 8,000$ more per year in retirement on average than nonmarried women. Using the decomposition framework, this gap favoring men is accounted for mainly by differences in men's and women's labor market histories. Thus roughly one-third of the gap is due to differences in average prime-age earnings, one-third to differential occupational segregation, and 15 percent to different lengths of labor market attachment. The potent role of the labor market variables for the nonmarried groups is reiterated for each of the three income types, though by far the most powerful influence is for income other than pensions and Social Security. Thus labor market differences account for more than the entire gap in non-pension, non-Social Security income, indicating that if women had men's labor market experience, pay, and occupational patterns, the retirement income gap would be expected to be more than fully closed. ${ }^{26}$

Taken as a whole, the decomposition results confirm the central role of labor market variables in accounting for projected retirement gaps by sex. Thus a nonmarried woman with lifetime labor force

\footnotetext{
${ }^{26}$ A more detailed examination of the non-pension, non-Social Security wealth differences between nonmarried men and women indicates that the major source of this gap comes from financial assets rather than housing wealth. Housing wealth is essentially the same by sex among the nonmarried population. Analysis of the sources of nonhousing financial wealth, such as private business ownership, is beyond the scope of the present study.
} 
attachment, pay, and occupational attainment similar to those of her male counterpart could expect retirement income quite similar to his. ${ }^{27}$

\section{Conclusion}

The continuing problem of poverty among older people prompts analysts and policymakers to ask why some groups have a high likelihood of being poor in old age. Other studies have investigated the role of marital status changes - widowhood in particular - in influencing women's old-age income status. Here we take a different tack, asking instead how different labor market events affect anticipated retirement incomes. Our specific focus has been to explore the role of earnings patterns, years of labor market experience, and occupational segregation; in addition, we control for differences in other socioeconomic factors. Using the Health and Retirement Study, we construct measures of projected retirement income based on anticipated Social Security, pension, and other financial wealth.

Our analysis proceeded in stages. First we established the size of anticipated gaps in projected retirement wealth. We found that the typical married couple looks forward to around half a million dollars in retirement assets, while the median nonmarried man has about $\$ 190,000$ and the median nonmarried woman about $\$ 160,000$. These asset levels were in turn converted into annual retirement income flows, where women's longer life expectancies in retirement exacerbate the gender gap. But we

27 A similar multivariate approach shows that anticipated retirement income does not vary much as a function of prior marital history among nonmarried men, but it does for women. That is, the median nevermarried woman expects about 60 percent more retirement income than nonmarried divorced or widowed women. The main source of this difference is pension income: the median never-married woman expects over $\$ 2,000$ in annual pension benefits, while the median widowed and divorced woman expects none. The values may in fact actually be closer than they appear in our data. This is because divorced and widowed respondents have claims to the Social Security benefits of their former spouses if they had been married for at least 10 years prior to the marital breakup (the 10-year requirement does not pertain to a spouse who becomes widowed while still married). On the other hand, our estimate of Social Security wealth for divorced and widowed women will be somewhat understated for those who had been married at least a 
concluded that the main reason older nonmarried women on the verge of retirement should anticipate lower levels of retirement income than their male counterparts is that they have much lower retirement assets than do other demographic groups. This gap was most prominent for Whites; Blacks and Hispanics have fewer assets and consequently a smaller gap by sex. Nonmarried Black and Hispanic men and women expect relatively little income from sources other than Social Security. The median nonmarried minority in the sample will not receive any employer pension income and only modest income from other financial assets.

The second stage of the analysis explored the factors associated with differences in anticipated retirement income. Here we ask to what extent differences in these factors can explain why women arrive on the doorstep of retirement with fewer resources and lower projected income as compared to men. Our results suggested that an additional year of labor market work between the ages of 20 and 50 has a relatively small effect on men's and women's retirement income, holding other things constant. An additional $\$ 1,000$ in average annual earnings raises women's retirement income, but by much less than it improves men's retirement income. Interestingly, women who worked in occupations with a higher proportion of females anticipate lower total retirement income than do women in less concentrated occupations; the occupational mix variable is not statistically significant for men. This difference may be due to the fact that jobs dominated by women were less likely to offer pensions and other employee benefits which could imply that women's financial emergencies might translate into lower saving. Confirmation of this new hypothesis awaits further analysis of nonmarried women's saving patterns. Overall, the model indicates that closing the sex gap in years of work, average pay, and

decade, since the EBF file does not report Social Security earnings and benefits for previous spouses because of confidentiality restrictions; see Mitchell, Olson and Steinmeier (forthcoming). 
occupational attainment could help shrink quite substantially the retirement income gap for nonmarried people. That is, $85 \%$ of the overall retirement income gap would be eliminated if, over their lifetimes, women and men had similar lifetime earnings, labor market attachment, and occupational attainment.

Looking ahead, what might be projected regarding the future? If women's pay levels continue to climb over time as they have in the last decade or so, future cohorts of women approaching retirement will have earned more over their lifetimes, enhancing their well being both absolutely and relative to men. The same holds true regarding the slower, but steady, observed fall in occupational segregation over time. 
Table 1. Median Projected Retirement Wealth by Race/Ethnicity, Sex, and Current Marital Status

\begin{tabular}{l|cc|cc|cc|c} 
& \multicolumn{2}{|c|}{ White } & \multicolumn{2}{c|}{ Black } & \multicolumn{2}{c}{ Hispanic } & All \\
Men & Nonmarried & Married & Nonmarried & Married & Nonmarried & Married & Nonmarried \\
Married
\end{tabular}

(Housing + Net Fin)

\begin{tabular}{|c|c|c|c|c|c|c|c|c|}
\hline \multirow[b]{2}{*}{ Women } & \multicolumn{2}{|c|}{ White } & \multicolumn{2}{|c|}{ Black } & \multicolumn{2}{|c|}{ Hispanic } & \multicolumn{2}{|c|}{ All } \\
\hline & Nonmarried & Married & Nonmarried & Married & Nonmarried & Married & Nonmarried & Married \\
\hline $\begin{array}{l}\text { Total Projected } \\
\text { Household Wealth }\end{array}$ & & & & & & & & \\
\hline Total Wealth & $\$ 179,904$ & $\$ 555,309$ & $\$ 105,703$ & $\$ 332,656$ & $\$ 71,929$ & $\$ 252,618$ & $\$ 157,098$ & $\$ 530,032$ \\
\hline Social Security Wealth & $\$ 66,548$ & $\$ 185,786$ & $\$ 60,685$ & $\$ 158,330$ & $\$ 47,544$ & $\$ 135,912$ & $\$ 63,642$ & $\$ 183,018$ \\
\hline Pension Wealth & $\$ 3,985$ & $\$ 104,393$ & $\$ 0$ & $\$ 99,319$ & $\$ 0$ & $\$ 717$ & $\$ 0$ & $\$ 98,247$ \\
\hline Other Wealth & $\$ 56,026$ & $\$ 179,477$ & $\$ 18,114$ & $\$ 60,534$ & $\$ 1,531$ & $\$ 52,020$ & $\$ 45,711$ & $\$ 161,969$ \\
\hline
\end{tabular}

(Housing + Net Fin) 
Table 2. Median Projected Annual Retirement Income by Race/Ethnicity, Sex, and Current Marital Status

\begin{tabular}{|c|c|c|c|c|c|c|c|c|}
\hline \multirow[b]{2}{*}{ Men } & \multicolumn{2}{|c|}{ White } & \multicolumn{2}{|c|}{ Black } & \multicolumn{2}{|c|}{ Hispanic } & \multicolumn{2}{|c|}{ All } \\
\hline & Nonmarried & Married & Nonmarried & Married & Nonmarried & Married & Nonmarried & Married \\
\hline $\begin{array}{l}\text { Total Projected Annual } \\
\text { Household Income }\end{array}$ & & & & & & & & \\
\hline$\overline{\text { Total Income }}$ & $\$ 15,756$ & $\$ 30,123$ & $\$ 5,040$ & $\$ 18,628$ & $\$ 6,080$ & $\$ 12,301$ & $\$ 12,950$ & $\$ 28,023$ \\
\hline Social Security Income & $\$ 5,968$ & $\$ 9,316$ & $\$ 3,593$ & $\$ 7,418$ & $\$ 4,079$ & $\$ 6,576$ & $\$ 5,500$ & $\$ 9,095$ \\
\hline Pension Income & $\$ 2,312$ & $\$ 7,062$ & $\$ 0$ & $\$ 5,425$ & $\$ 0$ & $\$ 114$ & $\$ 1,699$ & $\$ 6,240$ \\
\hline Other Income & $\$ 3,832$ & $\$ 9,005$ & $\$ 57$ & $\$ 3,818$ & $\$ 385$ & $\$ 3,116$ & $\$ 2,618$ & $\$ 8,309$ \\
\hline
\end{tabular}

(Housing + Net Fin)

\begin{tabular}{|c|c|c|c|c|c|c|c|c|}
\hline \multirow[b]{2}{*}{ Women } & \multicolumn{2}{|c|}{ White } & \multicolumn{2}{|c|}{ Black } & \multicolumn{2}{|c|}{ Hispanic } & \multicolumn{2}{|c|}{ All } \\
\hline & Nonmarried & Married & Nonmarried & Married & Nonmarried & Married & Nonmarried & Married \\
\hline \multicolumn{9}{|l|}{$\begin{array}{l}\text { Total Projected Annual } \\
\text { Household Income }\end{array}$} \\
\hline Total Income & $\$ 10,246$ & $\$ 30,790$ & $\$ 6,042$ & $\$ 18,942$ & $\$ 4,115$ & $\$ 14,675$ & $\$ 9,016$ & $\$ 29,479$ \\
\hline Social Security Income & $\$ 3,821$ & $\$ 10,226$ & $\$ 3,489$ & $\$ 8,749$ & $\$ 2,735$ & $\$ 7,979$ & $\$ 3,637$ & $\$ 10,135$ \\
\hline Pension Income & $\$ 230$ & $\$ 5,881$ & $\$ 0$ & $\$ 5,425$ & $\$ 0$ & $\$ 41$ & $\$ 0$ & $\$ 5,474$ \\
\hline $\begin{array}{l}\text { Other Income } \\
\text { (Housing + Net Fin })\end{array}$ & $\$ 3,198$ & $\$ 9,871$ & $\$ 1,042$ & $\$ 3,337$ & $\$ 87$ & $\$ 3,116$ & $\$ 2,626$ & $\$ 9,051$ \\
\hline
\end{tabular}

Source: Authors' calculations, Health and Retirement Study W1 (\$1992)

Note: All data weighted by HRS sample weights. 
Table 3. Predicted Changes in Total Projected Annual Retirement Income Associated with

Kev Exblanatorv Variables (standard errors in varentheses)

\begin{tabular}{|c|c|c|c|c|}
\hline Change in Explanatorv Variable & $\begin{array}{c}\text { Nonmarried } \\
\text { Women }\end{array}$ & $\begin{array}{c}\text { Nonmarried } \\
\text { Men }\end{array}$ & $\begin{array}{l}\text { Married } \\
\text { Women }\end{array}$ & $\begin{array}{c}\text { Married } \\
\text { Men }\end{array}$ \\
\hline \multicolumn{5}{|l|}{ +1 Year of Work } \\
\hline Total Retirement Income & $\$ 94$ & $-\$ 247$ & $-\$ 203$ & $-\$ 332$ \\
\hline & (107) & (331) & (109) & (169) \\
\hline Social Securitv Income & $\$ 90$ & $\$ 64$ & $\$ 38$ & $\$ 159$ \\
\hline & (19) & (47) & (10) & (24) \\
\hline Pension Income & $-\$ 74$ & $-\$ 778$ & $-\$ 102$ & $-\$ 455$ \\
\hline & $(100)$ & $(395)$ & $(82)$ & $(128)$ \\
\hline Other Income & $-\$ 17$ & $\$ 32$ & $-\$ 251$ & $-\$ 425$ \\
\hline & $(147)$ & $(486)$ & $(117)$ & $(211)$ \\
\hline \multicolumn{5}{|l|}{ +\$1.000 Average Prime-age Earnings } \\
\hline Total Retirement Income & $\$ 237$ & $\$ 570$ & $\$ 268$ & $\$ 362$ \\
\hline \multirow{2}{*}{ Social Securitv Income } & $\$ 59$ & $\$ 81$ & $\begin{array}{l}(97) \\
\$ 24\end{array}$ & $\begin{array}{l}(62) \\
\$ 48\end{array}$ \\
\hline & (20) & (37) & (9) & $(11)$ \\
\hline \multirow[t]{2}{*}{ Pension Income } & $\$ 130$ & $\$ 216$ & $\$ 106$ & $\$ 80$ \\
\hline & (77) & $(151)$ & $(70)$ & (49) \\
\hline \multirow[t]{2}{*}{ Other Income } & $\$ 193$ & $\$ 380$ & $\$ 190$ & $\$ 405$ \\
\hline & (113) & $(187)$ & (91) & (83) \\
\hline \multicolumn{5}{|l|}{$+\mathbf{1 0} \%$ Female Occupation } \\
\hline Total Retirement Income & $\begin{array}{l}-\$ 424 \\
(107)\end{array}$ & $-\$ 125$ & $-\$ 328$ & $\begin{array}{c}\$ 92 \\
(118)\end{array}$ \\
\hline \multirow[t]{2}{*}{ Social Securitv Income } & $-\$ 20$ & $\$ 9$ & $-\$ 10$ & $\$ 10$ \\
\hline & (13) & (13) & (18) & (10) \\
\hline \multirow[t]{2}{*}{ Pension Income } & $-\$ 174$ & $-\$ 34$ & $-\$ 391$ & $\$ 205$ \\
\hline & $(119)$ & $(238)$ & $(153)$ & $(84)$ \\
\hline \multirow[t]{2}{*}{ Other Income } & $-\$ 423$ & $-\$ 269$ & $-\$ 207$ & $-\$ 303$ \\
\hline & $(176)$ & $(226)$ & $(257)$ & $(133)$ \\
\hline
\end{tabular}

Source: Authors' calculations. Health and Retirement Studv W1 (\$1992) 
Table 4. Decomposing Differences in Retirement Income by Type: Fraction Attributable to Differences in Respondent Characteristics

$\underline{\text { Nonmarried Men vs Women }}$

Av. Total Retirement Income Gap

Percentage of gap attributable to: $\underline{\text { Total }} *$

$\$ 8,041$ $\underline{\text { Pension** }}$

$\$ 5,396$

$\$ 1,395$

$\mathbf{8 8 \%}$

$29 \%$

$398 \%$

Years of Work to Age 50

Average Prime-Age Earnings

$\%$ Female in Occupation
$85 \%$

$15 \%$

$35 \%$

$35 \%$
$46 \%$

$34 \%$

$8 \%$
Other**

$\$ 3,297$
$198 \%$

$21 \%$

$15 \%$

$241 \%$

Source: Authors' calculations, Health and Retirement Study W1 (\$1992), weighted data.

* Nonnegative wealthholders only.

**Positive wealthholders only.

Note: Decompositions use regression coefficients reported in Appendix Table A2 and means reported in Appendix Table A1. 


\section{Data Appendix}

In this study we use age 62 as the common age at which retirement assets are computed. This is the modal age for Social Security benefit filing purposes and is the earliest age at which one can currently file for Social Security benefits. While it is straightforward to specify an assumed retirement age for a nonmarried individual, it is more complex for a married couple since the retirement date for spouses of differing ages may differ. Here we follow HRS practice where the survey interviewer designated as the "primary respondent" that household member having the greatest knowledge of the household's financial matters. Usually this respondent was age-eligible for the HRS survey in which case we assume the retirement assumption is triggered on this person's attainment of age 62. If the primary respondent was not HRS age-eligible, this guarantees that the secondary respondent is age-eligible. In this instance, we assume that the age-eligible household member keys off retirement at the attainment of age 62 .

Values for each of the main retirement asset classes are projected to retirement using a range of projection technologies and assumptions (the approach is described in Moore and Mitchell, forthcoming). In brief, net financial wealth is projected forward using averages of market returns based on historical rates; housing wealth is projected forward using survey data on the purchase price of the respondent's house, year of purchase, outstanding debt owed on homes, and mortgage payment amount and frequency. We assume that the market value of the house grows in line with the general inflation rate so there is no real appreciation in housing values though mortgage payments decrease the remaining principal on the mortgage. Respondents' pension and Social Security wealth values are projected assuming workers remain employed to their retirement age (see Gustman et al., forthcoming). Pension benefits are derived based on the plan provisions of employer provided pensions and respondents' answers to salary and years of service (where appropriate). Social Security projected amounts are computed as described in Mitchell, Olson, and Steinmeier (forthcoming) for those respondents agreeing to supply a data link; for them we also have available work history and average pay variables for each respondent. This includes average lifetime salary and total labor market experience up to age 50. Present values of benefits are calculated using mortality, interest rate, inflation, and wage growth assumptions as described in Moore and Mitchell (forthcoming). All dollar values are given in $\$ 1992$. After the death of one spouse, we assume that remaining housing and net financial assets transfer to the survivor; Social Security benefits are available to the widow(er) according to program rules; and pension rules now require survivor benefits unless a spouse agrees to the contrary in writing. Other research studies using some of these data include Dwyer and Mitchell (forthcoming), Gustman et al. (forthcoming), Mitchell and Moore (forthcoming), and Mitchell et al. (1998).

We eliminate from the analysis any sample respondents with negative projected total wealth at age 62 (8 individuals), and to produce viable log values, we impute one dollar of wealth to respondents reporting zero total wealth. Similar issues arise with the components of total wealth, namely Social Security, employer pensions, and housing/financial wealth. The last category, which we term "other wealth" here, is the aggregate of financial and housing wealth. It too can take on negative and zero values. The empirical analysis of these other wealth values proceeds in the same fashion as the total wealth analysis: persons reporting negative values are dropped from the sample, and cases with zero wealth are assigned one dollar. There are no negative reports of employer pension wealth in the sample, but $32 \%$ of the respondents report they anticipate no employer pension. Persons without pensions are excluded from the analysis of employer pension wealth. We have separately estimated, but do not describe here, additional Probit models to explore factors associated with having positive values of each type of wealth. Controlling for sample selection does not change the qualitative conclusions reported here.

The explanatory variables in the multivariate analysis control for various socioeconomic characteristics of survey households (descriptive statistics appear in Appendix Table 1). We also include controls for spouse variables for married couples, which must be included because retirement wealth measures relate to households rather than individuals. In all cases, missing values for explanatory variables are assigned a flag variable that is then included in all estimates. While some explanatory variables (age, race, and education) do not require description, others (like share of women in longest occupation) require a brief description as follows:

Marital History Variables: We estimate separate equations for currently married and nonmarried men and women, but each set of estimates controls for respondents' marital history. Qualitative variables identifying previous divorce 
and widowhood appear in each equation, where the omitted category varies depending on the sample group. (For example, in the case of single women, the omitted category is never married; for married women it is married). In separate analyses we also focus on the never-married, divorced, and widowed among the nonmarried population; however sample sizes are small.

Percent Female in Longest Occupation: The HRS provides two-digit occupation codes (OC) for three types of jobs: current, last, and a previous job of at least 5 years duration held after 1972. If a respondent was working in 1992, the survey recorded a respondent's OC and the number of years the respondent had been working at that current job. The survey then asked about any previous jobs that lasted at least 5 years after 1972. If the respondent had worked at such a job, tenure and OC of that job is recorded. If the respondent was not working in 1992, the survey then asked about the respondent's last job. If the last job ended after 1972, the survey collected OC and tenure for that job. If the respondent had held a job prior to his or her last job that lasted longer than 5 years, the OC and tenure for that job were recorded. Therefore, given a respondent's current job status, a respondent can have at most two jobs with OC and tenure data. For the present analysis we selected an occupation code for the respondent's longest job based on length of tenure for the two jobs reported, and assigned fraction of women in that two-digit occupation based on Levine and Zimmerman (1995) who devise these figures for the 1980 Census. That year is appropriate since it best reflects the gender composition of our sample workers' occupations while the HRS respondents were in their prime working years. Respondents in the military are assigned a military "flag" variable since fraction female is not available from this source that year. If the respondent never worked for pay (as defined above), a flag variable (NO_WORK) was set to one. If the respondent worked, but did not report an occupation code, the flag variable MISSING was set equal to one. In all cases where we could not match a respondent's occupation to the share of women in it, we substitute the mean percentage of women. 
Appendix Table 1. Mean Values of Explanatory Variables by Sex and Marital Status

\begin{tabular}{|c|c|c|c|c|c|c|c|c|}
\hline & \multicolumn{2}{|c|}{$\underline{\text { Nonmarried Women }}$} & \multicolumn{2}{|c|}{$\underline{\text { Nonmarried Men }}$} & \multicolumn{2}{|c|}{$\underline{\text { Married Women }}$} & \multicolumn{2}{|c|}{$\underline{\text { Married Men }}$} \\
\hline & Mean & $\frac{\text { Standard }}{\text { Deviation }}$ & $\underline{\text { Mean }}$ & $\frac{\text { Standard }}{\text { Deviation }}$ & Mean & $\frac{\text { Standard }}{\text { Deviation }}$ & Mean & $\begin{array}{l}\text { Standard } \\
\text { Deviation }\end{array}$ \\
\hline \multicolumn{9}{|c|}{ Projected Household Wealth } \\
\hline Total & $\$ 241,242$ & 277,189 & $\$ 326,074$ & 433,748 & $\$ 719,538$ & 773,943 & $\$ 751,791$ & 881,280 \\
\hline Social Security & $\$ 66,644$ & 30,551 & $\$ 78,274$ & 27,614 & $\$ 172,582$ & 47,863 & $\$ 161,886$ & 45,747 \\
\hline Pension & $\$ 65,477$ & 131,336 & $\$ 110,641$ & 169,451 & $\$ 197,844$ & 282,008 & $\$ 227,682$ & 314,672 \\
\hline Other Wealth & $\$ 109,121$ & 217,946 & $\$ 137,159$ & 362,892 & $\$ 349,113$ & 706,053 & $\$ 362,224$ & 818,496 \\
\hline \multicolumn{9}{|c|}{ Projected Annual HH Income } \\
\hline Total & $\$ 13,822$ & 15,873 & $\$ 21,788$ & 28,884 & $\$ 40,116$ & 42,802 & $\$ 39,894$ & 47,032 \\
\hline Social Security & $\$ 3,817$ & 1,752 & $\$ 5,234$ & 1,853 & $\$ 9,663$ & 2,808 & $\$ 8,608$ & 2,604 \\
\hline Pension & $\$ 3,747$ & 7,513 & $\$ 7,385$ & 11,304 & $\$ 11,018$ & 15,757 & $\$ 12,042$ & 16,556 \\
\hline Other Income & $\$ 6,292$ & 12,466 & $\$ 9,234$ & 24,129 & $\$ 19,460$ & 38,881 & $\$ 19,272$ & 43,601 \\
\hline \multicolumn{9}{|l|}{ Labor Market Variables } \\
\hline Years of Work to Age 50 & 18.51 & 8.55 & 25.12 & 6.75 & 15.64 & 8.44 & 26.26 & 6.21 \\
\hline Average Earnings & $\$ 10,017$ & $\$ 7,411$ & $\$ 18,678$ & $\$ 9,283$ & $\$ 8,196$ & $\$ 6,208$ & $\$ 22,587$ & $\$ 8,591$ \\
\hline Occupation (\% female) & 0.55 & 0.20 & 0.33 & 0.23 & 0.55 & 0.19 & 0.31 & 0.20 \\
\hline \multicolumn{9}{|l|}{ Socioeconomic factors } \\
\hline Age & 55.93 & 3.21 & 55.55 & 3.13 & 55.85 & 3.16 & 55.94 & 3.17 \\
\hline Black (\%) & 0.19 & 0.39 & 0.17 & 0.38 & 0.06 & 0.23 & 0.07 & 0.25 \\
\hline Hispanic (\%) & 0.06 & 0.23 & 0.07 & 0.25 & 0.04 & 0.20 & 0.05 & 0.22 \\
\hline No High School (\%) & 0.30 & 0.46 & 0.28 & 0.45 & 0.20 & 0.40 & 0.22 & 0.41 \\
\hline College $(\%)$ & 0.07 & 0.26 & 0.10 & 0.30 & 0.09 & 0.29 & 0.12 & 0.33 \\
\hline Graduate School (\%) & 0.09 & 0.29 & 0.07 & 0.26 & 0.05 & 0.22 & 0.11 & 0.31 \\
\hline Ever Divorced (\%) & 0.63 & 0.48 & 0.68 & 0.47 & 0.22 & 0.41 & 0.27 & 0.44 \\
\hline Ever Widowed (\%) & 0.35 & 0.48 & 0.10 & 0.31 & 0.04 & 0.20 & 0.02 & 0.14 \\
\hline Number of Children & 2.77 & 2.01 & 2.07 & 1.92 & 3.48 & 1.98 & 3.30 & 1.97 \\
\hline
\end{tabular}

Note: Earnings reported in 1992 dollars (not in natural logs)

Source: Authors' calculations, Health and Retirement Study W1 (\$1992), weighted data. 
Appendix Table 1. (continued)

\begin{tabular}{|c|c|c|c|c|c|c|c|c|}
\hline & \multicolumn{2}{|c|}{ Nonmarried Women } & \multicolumn{2}{|c|}{ Nonmarried Men } & \multicolumn{2}{|c|}{ Married Women } & \multicolumn{2}{|c|}{ Married Men } \\
\hline & $\underline{\text { Mean }}$ & $\frac{\text { Standard }}{\underline{\text { Deviation }}}$ & $\underline{\text { Mean }}$ & $\frac{\text { Standard }}{\underline{\text { Deviation }}}$ & $\underline{\text { Mean }}$ & $\frac{\text { Standard }}{\underline{\text { Deviation }}}$ & $\underline{\text { Mean }}$ & $\frac{\text { Standard }}{\text { Deviation }}$ \\
\hline \multicolumn{9}{|l|}{ Labor Market Variables } \\
\hline \multicolumn{9}{|l|}{ for Spouse } \\
\hline Years of Work to Age 50 & -- & -- & -- & -- & 25.7 & 5.26 & 18.4 & 7.79 \\
\hline Average Earnings & -- & -- & -- & -- & 20,097 & 7,669 & 10,177 & 6,439 \\
\hline Occupation (\% female) & -- & -- & -- & -- & 0.43 & 0.23 & 0.43 & 0.22 \\
\hline \multicolumn{9}{|l|}{ Socioeconomic factors } \\
\hline \multicolumn{9}{|l|}{ for Spouse } \\
\hline Age & -- & -- & -- & -- & 59.0 & 5.85 & 52.4 & 5.86 \\
\hline No High School (\%) & -- & -- & -- & -- & 0.24 & 0.43 & 0.17 & 0.38 \\
\hline College $(\%)$ & -- & -- & -- & -- & 0.12 & 0.32 & 0.10 & 0.30 \\
\hline Graduate School (\%) & -- & -- & -- & -- & 0.10 & 0.30 & 0.05 & 0.23 \\
\hline Ever Divorced (\%) & -- & -- & -- & -- & 0.20 & 0.40 & 0.22 & 0.41 \\
\hline Ever Widowed (\%) & -- & -- & -- & -- & 0.05 & 0.21 & 0.03 & 0.17 \\
\hline
\end{tabular}

Note: Earnings reported in 1992 dollars (not in natural logs)

Source: Authors' calculations, Health and Retirement Study W1 (\$1992), weighted data. 


\section{Appendix Table 2. Regression Results for Projected Retirement} Income by Type: Coefficients (Standard Errors)

\begin{tabular}{|c|c|c|c|c|}
\hline $\begin{array}{l}\text { A. Nonmarried Women } \\
\text { Labor Market Variables }\end{array}$ & Total & \begin{tabular}{|l|} 
Social \\
Security \\
\end{tabular} & Pension & Other \\
\hline Years of Work to Age 50 & $\begin{array}{l}0.01 \\
(0.01)\end{array}$ & $\begin{array}{l}0.02 * * \\
(0.01)\end{array}$ & $\begin{array}{l}-0.01 \\
(0.01)\end{array}$ & $\begin{array}{l}0.00 \\
(0.02)\end{array}$ \\
\hline Average Prime-age Earnings & $\begin{array}{l}0.17^{*} \\
(0.07)\end{array}$ & $\begin{array}{l}0.16^{* *} \\
(0.05)\end{array}$ & $\begin{array}{l}0.22 \\
(0.13)\end{array}$ & $\begin{array}{l}0.29 \\
(0.17)\end{array}$ \\
\hline Percent Female in Occupation & $\begin{array}{l}-0.55 * * \\
(0.14) \\
\end{array}$ & $\begin{array}{l}-0.09 \\
(0.06)\end{array}$ & $\begin{array}{l}-0.41 \\
(0.28)\end{array}$ & $\begin{array}{l}-1.12 * \\
(0.47)\end{array}$ \\
\hline \multicolumn{5}{|l|}{$\underline{\text { Socioeconomic factors }}$} \\
\hline Age & $\begin{array}{l}0.02 * \\
(0.01)\end{array}$ & $\begin{array}{l}0.03 * * \\
(0.01)\end{array}$ & $\begin{array}{l}-0.05 * * \\
(0.02)\end{array}$ & $\begin{array}{l}0.06 \\
(0.03)\end{array}$ \\
\hline Black & $\begin{array}{l}-0.22 * * \\
(0.08)\end{array}$ & $\begin{array}{l}-0.13^{*} \\
(0.06)\end{array}$ & $\begin{array}{l}0.43^{* *} \\
(0.10)\end{array}$ & $\begin{array}{l}-1.17 * * \\
(0.25)\end{array}$ \\
\hline Hispanic & $\begin{array}{l}-0.18 \\
(0.11)\end{array}$ & $\begin{array}{l}0.15 \\
(0.08)\end{array}$ & $\begin{array}{l}-0.57 \\
(0.33)\end{array}$ & $\begin{array}{l}-1.74 * * \\
(0.46)\end{array}$ \\
\hline No High School & $\begin{array}{l}-0.62 * * \\
(0.08)\end{array}$ & $\begin{array}{l}-0.17 * * \\
(0.04)\end{array}$ & $\begin{array}{l}-0.35^{*} \\
(0.14)\end{array}$ & $\begin{array}{l}-1.63 * * \\
(0.25)\end{array}$ \\
\hline College & $\begin{array}{l}0.44 * * \\
(0.12)\end{array}$ & $\begin{array}{l}-0.03 \\
(0.05)\end{array}$ & $\begin{array}{l}0.58 * * \\
(0.19)\end{array}$ & $\begin{array}{l}0.80 * * \\
(0.30)\end{array}$ \\
\hline Graduate School & $\begin{array}{l}0.76 * * \\
(0.12)\end{array}$ & $\begin{array}{l}0.10 \\
(0.13)\end{array}$ & $\begin{array}{l}0.90 * * \\
(0.18)\end{array}$ & $\begin{array}{l}0.94 * * \\
(0.36)\end{array}$ \\
\hline Ever Divorced & $\begin{array}{l}-0.16^{*} \\
(0.07)\end{array}$ & $\begin{array}{l}-0.08 \\
(0.05)\end{array}$ & $\begin{array}{l}-0.23 \\
(0.15)\end{array}$ & $\begin{array}{l}-0.45 \\
(0.27)\end{array}$ \\
\hline Ever Widowed & $\begin{array}{l}0.10 \\
(0.07)\end{array}$ & $\begin{array}{l}-0.06 \\
(0.04)\end{array}$ & $\begin{array}{l}-0.23 \\
(0.15)\end{array}$ & $\begin{array}{l}0.57 \\
(0.30)\end{array}$ \\
\hline Number of Children & $\begin{array}{l}-0.04 * * \\
(0.02) \\
\end{array}$ & $\begin{array}{l}-0.01 \\
(0.02) \\
\end{array}$ & $\begin{array}{l}-0.09 * \\
(0.04)\end{array}$ & $\begin{array}{l}-0.03 \\
(0.06) \\
\end{array}$ \\
\hline $\begin{array}{l}R \text {-Squared } \\
\text { Samnle Size }\end{array}$ & $\begin{array}{l}0.41 \\
946\end{array}$ & $\begin{array}{l}0.39 \\
946\end{array}$ & $\begin{array}{l}0.27 \\
443\end{array}$ & $\begin{array}{l}0.26 \\
863\end{array}$ \\
\hline
\end{tabular}

Notes: See below 
Appendix Table 2 (cont).

B. Nonmarried Men

Labor Market Variables

Years of Work to Age 50

Average Prime-age Earnings

Percent Female in Occupation

$\underline{\text { Socioeconomic factors }}$

Age

Black

Hispanic

No High School

College

Graduate School

Ever Divorced

Ever Widowed

Number of Children

$R$-Squared

Sample Size

Notes: See below

\begin{tabular}{|l|l|l|l|}
\hline Total & $\begin{array}{l}\text { Social } \\
\text { Security }\end{array}$ & Pension & Other \\
\hline-0.01 & 0.01 & $-0.06^{*}$ & 0.00 \\
$(0.01)$ & $(0.01)$ & $(0.03)$ & $(0.05)$ \\
$0.49^{* *}$ & $0.29^{*}$ & 0.35 & $0.71^{*}$ \\
$(0.18)$ & $(0.13)$ & $(0.25)$ & $(0.35)$ \\
-0.18 & 0.05 & -0.08 & -0.83 \\
$(0.27)$ & $(0.08)$ & $(0.53)$ & $(0.70)$ \\
\hline & & & \\
0.02 & $0.03^{* *}$ & -0.05 & 0.10 \\
$(0.02)$ & $(0.01)$ & $(0.03)$ & $(0.06)$ \\
$-0.56^{* *}$ & $-0.21^{* *}$ & -0.14 & $-2.53^{* *}$ \\
$(0.12)$ & $(0.06)$ & $(0.26)$ & $(0.46)$ \\
-0.18 & -0.04 & 0.11 & -1.82 \\
$(0.21)$ & $(0.09)$ & $(0.26)$ & $(1.00)$ \\
$-0.32^{*}$ & -0.07 & -0.20 & $-0.77^{*}$ \\
$(0.12)$ & $(0.06)$ & $(0.22)$ & $(0.37)$ \\
$0.68^{* *}$ & $0.15^{*}$ & 0.46 & $0.92^{*}$ \\
$(0.22)$ & $(0.07)$ & $(0.33)$ & $(0.45)$ \\
$0.67^{* *}$ & 0.13 & 0.49 & $1.15^{*}$ \\
$(0.20)$ & $(0.08)$ & $(0.27)$ & $(0.50)$ \\
0.14 & 0.10 & $0.68^{* *}$ & -0.04 \\
$(0.14)$ & $(0.06)$ & $(0.25)$ & $(0.40)$ \\
0.09 & 0.01 & 0.57 & 0.11 \\
$(0.18)$ & $(0.08)$ & $(0.34)$ & $(0.60)$ \\
$-0.08^{* *}$ & -0.01 & -0.11 & -0.09 \\
$(0.03)$ & $(0.01)$ & $(0.06)$ & $(0.09)$ \\
\hline & & & \\
0.37 & 0.47 & 0.15 & 0.33 \\
404 & 404 & 212 & 373 \\
& & & \\
\hline & & & \\
\hline
\end{tabular}


Appendix Table 2 (cont).

\begin{tabular}{|c|c|c|c|c|}
\hline $\begin{array}{l}\text { C. Married Women } \\
\text { Labor Market Variables }\end{array}$ & Total & $\begin{array}{l}\text { Social } \\
\text { Security }\end{array}$ & Pension & Other \\
\hline Years of Work to Age 50 & $\begin{array}{l}-0.005 \\
(0.00)\end{array}$ & $\begin{array}{l}0.004 * * \\
(0.00)\end{array}$ & $\begin{array}{l}-0.01 \\
(0.01)\end{array}$ & $\begin{array}{l}-0.01 * \\
(0.01)\end{array}$ \\
\hline Average Prime-age Earnings & $\begin{array}{l}0.05 * * \\
(0.02)\end{array}$ & $\begin{array}{l}0.02 * * \\
(0.01)\end{array}$ & $\begin{array}{l}0.06 \\
(0.04)\end{array}$ & $\begin{array}{l}0.08 * \\
(0.04)\end{array}$ \\
\hline Percent Female in Occupation & $\begin{array}{l}-0.15 \\
(0.09)\end{array}$ & $\begin{array}{l}-0.02 \\
(0.03)\end{array}$ & $\begin{array}{l}-0.49 * * \\
(0.19)\end{array}$ & $\begin{array}{l}-0.19 \\
(0.24)\end{array}$ \\
\hline \multicolumn{5}{|l|}{$\underline{\text { Socioeconomic factors }}$} \\
\hline Age & $\begin{array}{l}0.00 \\
(0.01)\end{array}$ & $\begin{array}{l}0.01 * * \\
(0.00)\end{array}$ & $\begin{array}{l}0.00 \\
(0.01)\end{array}$ & $\begin{array}{l}0.02 \\
(0.02)\end{array}$ \\
\hline Black & $\begin{array}{l}-0.23 * * \\
(0.05)\end{array}$ & $\begin{array}{l}-0.08 * * \\
(0.02)\end{array}$ & $\begin{array}{l}0.20 * \\
(0.10)\end{array}$ & $\begin{array}{l}-0.84 * * \\
(0.16)\end{array}$ \\
\hline Hispanic & $\begin{array}{l}-0.35^{* *} \\
(0.07)\end{array}$ & $\begin{array}{l}-0.02 \\
(0.03)\end{array}$ & $\begin{array}{l}-0.21 \\
(0.24)\end{array}$ & $\begin{array}{l}-0.80 * * \\
(0.23)\end{array}$ \\
\hline No High School & $\begin{array}{l}-0.22 * * \\
(0.04)\end{array}$ & $\begin{array}{l}-0.06 * * \\
(0.02)\end{array}$ & $\begin{array}{l}-0.23^{* *} \\
(0.09)\end{array}$ & $\begin{array}{l}-0.55 * * \\
(0.12)\end{array}$ \\
\hline College & $\begin{array}{l}0.12 \\
(0.07)\end{array}$ & $\begin{array}{l}0.05 * \\
(0.02)\end{array}$ & $\begin{array}{l}0.07 \\
(0.11)\end{array}$ & $\begin{array}{l}0.25^{*} \\
(0.11)\end{array}$ \\
\hline Graduate School & $\begin{array}{l}0.39 * * \\
(0.07)\end{array}$ & $\begin{array}{l}0.06 \\
(0.03)\end{array}$ & $\begin{array}{l}0.48 * * \\
(0.12)\end{array}$ & $\begin{array}{l}0.57 * * \\
(0.13)\end{array}$ \\
\hline Ever Divorced & $\begin{array}{l}-0.16 * * \\
(0.05)\end{array}$ & $\begin{array}{l}-0.01 \\
(0.02)\end{array}$ & $\begin{array}{l}-0.15 \\
(0.11)\end{array}$ & $\begin{array}{l}-0.24 \\
(0.13)\end{array}$ \\
\hline Ever Widowed & $\begin{array}{l}-0.21 * \\
(0.09)\end{array}$ & $\begin{array}{l}-0.07 * \\
(0.03)\end{array}$ & $\begin{array}{l}-0.24 \\
(0.21)\end{array}$ & $\begin{array}{l}-0.40 \\
(0.23)\end{array}$ \\
\hline Number of Children & $\begin{array}{l}-0.02 * * \\
(0.01)\end{array}$ & $\begin{array}{l}0.00 \\
(0.00)\end{array}$ & $\begin{array}{l}0.00 \\
(0.02)\end{array}$ & $\begin{array}{l}-0.08 * * \\
(0.02)\end{array}$ \\
\hline \multicolumn{5}{|l|}{$\underline{\text { Labor Market Variables for Spouse }}$} \\
\hline Years of Work to Age 50 & $\begin{array}{l}-0.01 \\
(0.01)\end{array}$ & $\begin{array}{l}0.02 * * \\
(0.00)\end{array}$ & $\begin{array}{l}-0.03 * * \\
(0.01)\end{array}$ & $\begin{array}{l}-0.01 \\
(0.01)\end{array}$ \\
\hline Average Prime-age Earnings & $\begin{array}{l}0.18^{* *} \\
(0.04)\end{array}$ & $\begin{array}{l}0.14 * * \\
(0.03)\end{array}$ & $\begin{array}{l}0.12 \\
(0.07)\end{array}$ & $\begin{array}{l}0.35^{* *} \\
(0.08)\end{array}$ \\
\hline Percent Female in Occupation & $\begin{array}{l}0.16^{*} \\
(0.08)\end{array}$ & $\begin{array}{l}0.01 \\
(0.03)\end{array}$ & $\begin{array}{l}0.64 * * \\
(0.16)\end{array}$ & $\begin{array}{l}0.26 \\
(0.21)\end{array}$ \\
\hline \multicolumn{5}{|l|}{$\underline{\text { Socioeconomic factors }}$} \\
\hline Age & $\begin{array}{l}0.02 * * \\
(0.00)\end{array}$ & $\begin{array}{l}0.02 * * \\
(0.00)\end{array}$ & $\begin{array}{l}-0.01 \\
(0.01)\end{array}$ & $\begin{array}{l}0.03 * * \\
(0.01)\end{array}$ \\
\hline No High School & $\begin{array}{l}-0.27 * * \\
(0.04)\end{array}$ & $\begin{array}{l}-0.03 * \\
(0.01)\end{array}$ & $\begin{array}{l}-0.32 * * \\
(0.09)\end{array}$ & $\begin{array}{l}-0.53 * * \\
(0.10)\end{array}$ \\
\hline College & $\begin{array}{l}0.20 * * \\
(0.06)\end{array}$ & $\begin{array}{l}0.05 * * \\
(0.02)\end{array}$ & $\begin{array}{l}0.22 * \\
(0.11)\end{array}$ & $\begin{array}{l}0.34 * * \\
(0.09)\end{array}$ \\
\hline Graduate School & $\begin{array}{l}0.35 * * \\
(0.06)\end{array}$ & $\begin{array}{l}0.02 \\
(0.03)\end{array}$ & $\begin{array}{l}0.62 * * \\
(0.10)\end{array}$ & $\begin{array}{l}0.42 * * \\
(0.09)\end{array}$ \\
\hline Ever Divorced & $\begin{array}{l}0.02 \\
(0.05)\end{array}$ & $\begin{array}{l}0.00 \\
(0.02)\end{array}$ & $\begin{array}{l}-0.05 \\
(0.11)\end{array}$ & $\begin{array}{l}0.12 \\
(0.13)\end{array}$ \\
\hline Ever Widowed & $\begin{array}{l}0.16^{*} \\
(0.08)\end{array}$ & $\begin{array}{l}0.04 \\
(0.03)\end{array}$ & $\begin{array}{l}0.25 \\
(0.16)\end{array}$ & $\begin{array}{l}0.32 \\
(0.18)\end{array}$ \\
\hline $\begin{array}{l}R \text {-Squared } \\
\text { Sample Size }\end{array}$ & $\begin{array}{l}0.29 \\
2117\end{array}$ & $\begin{array}{l}0.54 \\
2117\end{array}$ & $\begin{array}{l}0.15 \\
1578\end{array}$ & $\begin{array}{l}0.21 \\
2075\end{array}$ \\
\hline
\end{tabular}

Notes: See below 
Appendix Table 2 (cont).

\section{Married Men}

Labor Market Variables

Years of Work to Age 50

Average Prime-age Earnings

Percent Female in Occupation

Socioeconomic factors

Age

Black

Hispanic

No High School

College

Graduate School

Ever Divorced

Ever Widowed

Number of Children

Labor Market Variables for Spouse

Years of Work to Age 50

Average Prime-age Earnings

Percent Female in Occupation

$\underline{\text { Socioeconomic factors }}$

Age

No High School

College

Graduate School

Ever Divorced

Ever Widowed

$R$-Squared

Sample Size

Notes: See below

\begin{tabular}{|c|c|c|c|}
\hline Total & $\begin{array}{l}\text { Social } \\
\text { Security }\end{array}$ & Pension & Other \\
\hline$-0.01 *$ & $0.02 * *$ & $-0.03 * *$ & $-0.02 *$ \\
\hline$(0.00)$ & $(0.00)$ & $(0.01)$ & $(0.01)$ \\
\hline $0.21 * *$ & $0.12 * *$ & 0.12 & $0.47 * *$ \\
\hline$(0.03)$ & $(0.03)$ & $(0.07)$ & $(0.10)$ \\
\hline 0.07 & 0.04 & $0.42 *$ & $-0.50 *$ \\
\hline$(0.10)$ & $(0.04)$ & $(0.17)$ & $(0.22)$ \\
\hline 0.00 & $0.01 * *$ & $-0.03 *$ & 0.02 \\
\hline$(0.01)$ & $(0.00)$ & $(0.01)$ & $(0.01)$ \\
\hline$-0.24 * *$ & $-0.07 * *$ & -0.06 & $-0.82 * *$ \\
\hline$(0.05)$ & $(0.02)$ & $(0.09)$ & $(0.15)$ \\
\hline$-0.39 * *$ & -0.02 & $-0.34 *$ & $-0.96 * *$ \\
\hline$(0.07)$ & $(0.03)$ & $(0.15)$ & $(0.25)$ \\
\hline$-0.25^{* *}$ & $-0.05 * *$ & $-0.20^{*}$ & $-0.47 * *$ \\
\hline$(0.04)$ & $(0.01)$ & $(0.09)$ & $(0.10)$ \\
\hline $0.23 * *$ & $0.07 * *$ & $0.33 * *$ & $0.39 * *$ \\
\hline$(0.06)$ & $(0.02)$ & $(0.10)$ & $(0.10)$ \\
\hline $0.39 * *$ & $0.07 * *$ & $0.51 * *$ & $0.62 * *$ \\
\hline$(0.06)$ & $(0.02)$ & $(0.10)$ & $(0.10)$ \\
\hline 0.00 & 0.02 & -0.05 & 0.06 \\
\hline$(0.05)$ & $(0.02)$ & $(0.09)$ & $(0.11)$ \\
\hline 0.18 & 0.00 & 0.26 & $0.43^{*}$ \\
\hline$(0.11)$ & $(0.03)$ & $(0.21)$ & $(0.20)$ \\
\hline$-0.04 * *$ & $-0.01 *$ & $-0.04 *$ & $-0.09 * *$ \\
\hline$(0.01)$ & $(0.00)$ & $(0.02)$ & $(0.02)$ \\
\hline$-0.01 * *$ & $0.002 *$ & -0.01 & $-0.02 * *$ \\
\hline$(0.00)$ & $(0.00)$ & $(0.01)$ & $(0.01)$ \\
\hline $0.09 * *$ & $0.03 * *$ & 0.09 & $0.13 *$ \\
\hline$(0.02)$ & $(0.01)$ & $(0.05)$ & $(0.06)$ \\
\hline-0.09 & $-0.07 *$ & -0.04 & -0.07 \\
\hline$(0.08)$ & $(0.03)$ & $(0.17)$ & $(0.17)$ \\
\hline $0.01 * *$ & $0.02 * *$ & 0.01 & $0.03 * *$ \\
\hline$(0.00)$ & $(0.00)$ & $(0.01)$ & $(0.01)$ \\
\hline$-0.20 * *$ & $-0.05 * *$ & $-0.23^{*}$ & $-0.39 * *$ \\
\hline$(0.04)$ & $(0.02)$ & $(0.10)$ & $(0.11)$ \\
\hline $0.16^{*}$ & 0.01 & 0.11 & $0.28 * *$ \\
\hline$(0.07)$ & $(0.02)$ & $(0.11)$ & $(0.11)$ \\
\hline $0.35 * *$ & 0.02 & $0.41 * *$ & $0.37 * *$ \\
\hline$(0.07)$ & $(0.03)$ & $(0.12)$ & $(0.12)$ \\
\hline-0.04 & 0.00 & 0.03 & -0.10 \\
\hline$(0.05)$ & $(0.02)$ & $(0.09)$ & $(0.11)$ \\
\hline-0.19 & $-0.08 *$ & 0.22 & -0.32 \\
\hline$(0.10)$ & $(0.03)$ & $(0.18)$ & $(0.21)$ \\
\hline 0.30 & 0.64 & 0.15 & 0.25 \\
\hline 2209 & 2209 & 1660 & 2147 \\
\hline
\end{tabular}


Appendix Table 2 (cont).

Notes:

1) Retirement income and average earnings expressed in natural logs.

2) Estimates exclude respondents with negative total wealth.

3) Pension Income estimates conditional on nonzero pension wealth.

4) Other Income estimates conditional on nonzero other wealth.

5) Information regarding the treatment of missing values appears in the data appendix.

Source: Authors' calculations, Health and Retirement Study W1 (\$1992)

** Coefficient statistically significant at the $1 \%$ level.

* Coefficient statistically significant at the $5 \%$ level. 


\section{References}

Blau, Francine D. and Marianne A. Ferber. "Discrimination: Empirical Evidence from the United States. American Economic Review. Vol. 77(2), 1987: 316-320.

Blau, F. D. and J. W. Graham. "Black-White Differences in Wealth and Asset Composition." Quarterly Journal of Economics. May 1990: 321-339.

Blau, Francine D. and Lawrence M. Kahn. "Swimming Upstream: Trends in the Gender Wage Differential in the Journal of Labor Economics. Vol. 15(1), 1997: 1-42.

Blau, Francine D., Marianne A. Ferber, and Anne E. Winkler. The Economics of Women, Men, and Work. New Jersey: Prentice Hall. 1998.

Blau, Francine D., Patricia Simpson, and Deborah Anderson. "Continuing Progress? Trends in Occupational Segregation in the United States over the 1970s and 1980s.” NBER Working Paper \#6716. September 1998.

Boskin, M. J. and J. B. Shoven. "Poverty Among the Elderly: Where are the Holes in the Safety Net?" in Z. Bodie, J. B. Shoven, and D. A. Wise (eds.), Pensions in the U.S. Economy. Chicago: University of Chicago Press, 1988: 115-138.

Burkhauser, R., J. S. Butler, and K. Holden. "How the Death of a Spouse Affects Economic Well-Being after Retirement: A Hazard Model Approach." Social Science Quarterly. September 1991: 504-519.

Burkhauser, R., J. S. Butler, and J. T. Wilkinson. "Estimating Changes in Well-Being Across Life: A Realized vs. Comprehensive Income Approach," in M. David and T. Smeeding (Eds.) Horizontal Equity, Uncertainty, and Economic Well-Being. Chicago: University of Chicago Press, 1985: 69-90.

Dwyer, Debra and Olivia S. Mitchell. "Health Problems as Determinants of Retirement: Are Self-Rated Measures Journal of Health Economics. 1998.

Filer, Randall K. "Occupational Segregation, Compensating Differentials, and Comparable Worth," in Pay Equity: Empirical Inquiries. Washington, DC: National Academy Press. 1989.

Gunderson, Morley. "Male-Female Wage differentials and Policy Responses." Journal of Economic Literature. Vol 27(1), 1989: 46-72.

Gustman, Alan, Olivia S. Mitchell, Andrew A. Samwick, and Thomas L. Steinmeier. "Pension and Social Security Wealth, Work, and Health: Innovations in Survey Measurement in the Social Sciences. Ed. Robert Willis. Forthcoming

Hurd, M. "The Poverty of Widows: Future Prospects," in The Economics of Aging. Ed. Wise. Chicago: University of Chicago Press, 1989: 201-230.

Johnson, George and Gary Solon. "Estimates of the Direct Effects of Comparable Worth Policy." American Economic Review. Vol. 76(5), 1986: 1117-1125.

Killingsworth, Mark. The Economics of Comparable Worth. Kalamazoo, MI: Upjohn Institute for Employment Research. 1990. 
Levine, Phillip B., Olivia S. Mitchell, and James Moore. "Women on the Verge of Retirement: Predictors of Retiree Retirement Accumulation and Decumulation. Eds. Brett Hammond Olivia S. Mitchell, and Anna Rappaport. Pension Research Council. Philadelphia: University of Pennsylvania Press, Forthcoming.

Levine, Phillip B. and David J. Zimmerman. "A Comparison of the Sex-Type of Occupational Aspirations and Subsequent Achievement." Work and Occupations. February 1995: 73-84.

Macpherson, David A. and Barry T. Hirsh. "Wages and Gender Composition: Why do Women's Jobs Pay Less?” Journal of Labor Economics. Vol. 13(3), 1995: 426-471.

McElroy, Marjorie R. "The Empirical Content of Nash-Bargained Household Behavior." Journal of Human Resources. Vol. 25 (4), Fall 1990, pages 559-583.

Mitchell, Olivia S. and James Moore. "Retirement Wealth Accumulation and Decumulation: New Developments and Journal of Risk and Insurance. 1998

Mitchell, Olivia S., James F. Moore, and John W. Phillips. "Explaining Retirement Saving Shortfalls." In Retirement Accumulation and Decumulation. Eds. Brett Hammond Olivia S. Mitchell, and Anna Rappaport. Pension Research Council. Philadelphia: University of Pennsylvania Press, Forthcoming.

Mitchell, Olivia S., Robert Myers, and Howard Young. Prospects for Social Security Reform. Pension Research Council. Philadelphia: University of Pennsylvania Press, 1999.

Mitchell, Olivia S., Jan Olson and Thomas Steinmeier. "Earnings and Social Security Benefits at Older Ages.” In Retirement Accumulation and Decumulation. Eds. Brett Hammond Olivia S. Mitchell, and Anna Rappaport. Pension Research Council. Philadelphia: University of Pennsylvania Press, Forthcoming.

Moon, Marilyn. The Measurement of Economic Welfare. New York: Academic Press. 1977.

Moore, James and Olivia S. Mitchell. "Projected Retirement Wealth and Saving Adequacy in the Health \& Retirement Retirement Accumulation and Decumulation. Eds. Brett Hammond Olivia S. Mitchell, and Anna Rappaport. Pension Research Council. Philadelphia: University of Pennsylvania Press, Forthcoming.

Nelson, J. A. "Household Equivalence Scales: Theory versus Policy?" Journal of Labor Economics. July 1993. pp. 471-493.

Oaxaca, Ronald L. "Male-Female Wage Differentials in Urban Labor Markets. International Economic Review. 1973: 693-709.

Porter, Kathryn H., Kathy Larin, and Wendell Primus. "Social Security and Poverty Among the Elderly". Working Paper, Center on Budget and Policy Priorities. Washington, D.C.: April 1999.

Ruggles, P. Drawing the Line: Alternative Poverty Measures and the Implications for Public Policy. Washington, DC: The Urban Institute Press. 1990.

Sorenson, Elaine. “The Crowding Hypothesis and Comparable Worth.” Journal of Human Resources. Vol. 25(1), 1990: 55-89.

Sorenson, Elaine. "Measuring the Effect of Occupational Sex and Race Composition on Earnings," in Pay Equity: Empirical Inquiries. Washington, DC: National Academy Press. 1989.

Weir, David R. and Robert Willis. "Prospects for Widow Poverty," in Olivia S. Mitchell, Bret Hammond, and Anna Rappaport (eds.), Forecasting Retirement Needs and Retirement Wealth. Philadelphia: University of Pennsylvania Press. forthcoming. 
</ref_section> 